\title{
Spiritual Intelligence and Its Relation with Psychological Stability of a Sample of Students from the College of Arts and Sciences in the University of Petra
}

\author{
Mahmoud J. Al-Salkhi \\ University of Petra \\ Amman, Jordan
}

\begin{abstract}
This study aims at investigating the level of spiritual intelligence as well as the level of the psychological stability of a sample of female students consisting of 127 individuals of various specialties including: Arabic Language, English Language, Chemistry, Educational Sciences, Modern Languages, and Mathematics. Also, the study aims to explore the connection relationship between two variables (Spiritual Intelligence and Psychological Stability). In order to accomplish the study objectives, the researcher used a measure for the spiritual intelligence level, and another measure for the psychological stability level. The study indicated a high level of both spiritual intelligence and psychological stability as reflected by the individual study samples. Also, the study indicated the absence of any statistical indicative differences that may be attributed to the academic level or the accumulative average. However, the study showed an existence of statistical indicative differences in the level of spiritual intelligence attributed to the area of specialty, and in favor of the educational sciences specialty. In addition, the study revealed the existence of a strong positive connection between spiritual intelligence and psychological stability.
\end{abstract}

Keywords: Spiritual Intelligence, Psychological Stability.

\section{Introduction}

The spiritual aspect is considered one of the characteristics that distinguishes human beings from animals, such as freedom and responsibility. In addition, the Spiritual aspect includes some important features such as: self-superiority, conscience, affection, faith, intuition, inspiration, and happiness (Luizcarlos, 2003). 
Also, spirituality indicates praying, meditation, interaction with others in a distinct manner, and self-satisfaction (Teichmann et al, 2006). In addition, spirituality covers feeling of peace, internal security, realizing the purpose of life and believing in its value.

Buzan (2006) noted that the spiritual concept means the energy of pure human life which is free from any material element such as feelings that include courage and enthusiasm. Spiritual intelligence relates to how character is acquired and developed as it relates to the development of the soul.

Spiritual intelligence is considered as the most important human intelligence due to its ability to change the human life and everything around it. Also, it demonstrates the principles and values as a balanced human behavior to achieve self-control, peaceful feelings, internal security, and closure to God. Human beings always try to achieve self-identification and a high spiritual state by behaving in a rational and balanced way, and being indulgent with others (Mamin, 2008, Jordan et al, 2008).

Zohar \& Marshall (2000) presented the Spiritual intelligence as the highest model of human intelligences as shown in the following figure:

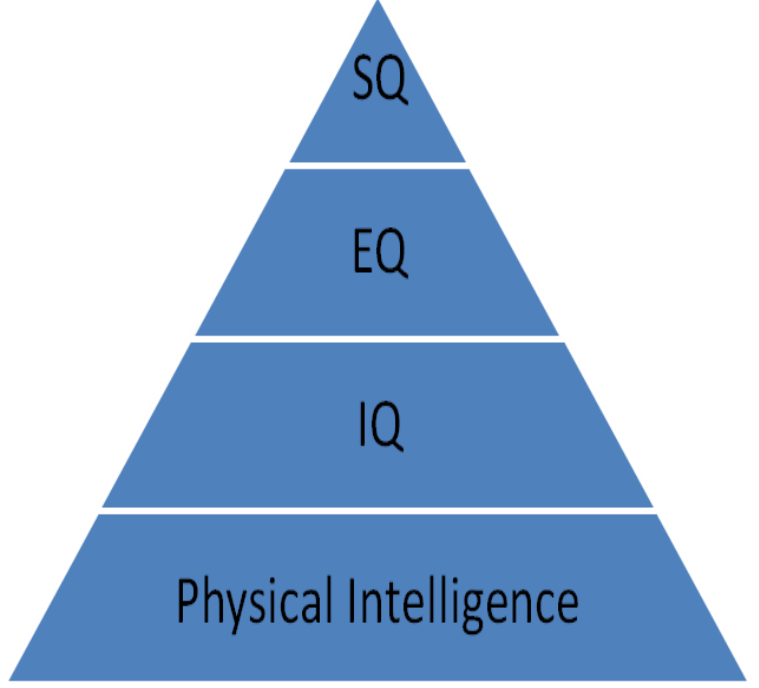

Figure 1: Model of various Human Intelligences

As shown in the above figure, Spiritual Intelligence (SQ) represents the highest model compared to the other human intelligences. Also, the figure indicates a connection between the Spiritual Intelligence (SQ) and Emotional Intelligence (EQ).. It was emphasized by Wigglesworth (2011), Al-Rashid (2017), and AlMasri (2017) that the Spiritual Intelligence and Emotional Intelligence are connected with each other. The individual needs the basics of Emotional Intelligence required for a successful start of his spiritual growth. The selfawareness and compassion are considered important bases. When the spiritual growth starts developing, it will be supported by the Emotional Intelligence skills that lead to the enforcement of Spiritual Intelligence skills. As a result, the 
Spiritual Intelligence supports the ability to manifest the Emotional Intelligences, and also double the average of mental intelligence.

It is worth noting that spiritual intelligence is considered a type of human intelligence assimilated from a group of cognitive and excitable competences. This intelligence enables the individual to acquire self-awareness and the conception of the universe and interaction with it in order to achieve internal peace. The spiritual intelligence is considered one of the most updated intelligences. It is connected with the faith power that affects the relation of human beings with the creator. Also, spiritual intelligence enforces the individual to practice worship and religious duties (Gardner, 1999).

Spiritual intelligence is defined by (Sinetar, 2002) as the ability to understand one's self and others through life experience and stimulating the internal spiritual traits such as: creativity, responsibility, justice, and problem solving.

Also, the researcher defines spiritual intelligence as the individual's ability to conceive one-self and the universe focusing on the idea of Divinity to be able to know and believe in God, and realizes the way that leads to Him and follows Him in all circumstances.

Vaughan (2002) emphasized that the spiritual intelligence focuses on the internal life of mind and soul and its relationship to the life existence. It includes an indepth understanding of existential issues.

Spiritual intelligence provides us with more in-depth understanding of ourselves and the universe, and also contributes to critical thinking about the existence of life.

Spiritual intelligence is considered an important element in the individual progress since it works as a director for human behavior to differentiate between good and bad things. Also, it develops the individual's balance and helps him solve problems created as a result of life pressure. Therefore, it supports him in accomplishing his interests and ambitions.

Spiritual intelligence has a special positive effect on students; it helps them solve their problems and avoid negative attitudes. Also. it helps students handle their weakness and laziness in learning, and prevents all excitable things that confuse their thinking and attention. Therefore, spiritual intelligence is strongly connected with excitable factors (Saidy et al, 2009).

Amram \& Dryer (2007) emphasized that the person with spiritual intelligence uses his capabilities in an depth understanding of himself, and answering basic enquires. This intelligence gives him integrity by directing his behavior to the right way. 
(Dhar et al, 2008) refers to the understanding of the spiritual intelligence through three learning views:

- Cognitive Dimension: It covers investigating questions about existence, and trying to find answers to the existential issues, and the purpose of life.

- Behavioral Dimension: It covers the human being's spiritual activities such as contemplation, indulgence, honesty, optimism, and others.

- Emotional Dimension: It is related to the individual's feeling of peace, joy, compassion, sympathy, anger, fear, and appreciation of beauty.

The theory of (Horn \& Cattel, 1966) indicated that spiritual intelligence involves individual competences that help in concluding existence issues and solving problems. (King, 2008).

Spiritual intelligence requires critical thinking and concluding meaning that involves the individual beliefs. We should examine our failures as well as our successes in order to produce the meaning of our life and its application.

Wilbur (2001) noted that the spiritual intelligence develops and enhances in three stages:

- Beginning Stage in which the attention is focused on oneself through aiming to God for worship and gratitude which gives humans the feeling of satisfaction and gratitude.

- Conventional Level that requires cooperation with religion, and extending an individual's interests to himself and others.

- Post Conventional Level that denotes the movement from commitment to the religious and spiritual conceptions to the general awareness of oneself and understanding various styles that comply with reality.

Various theories were presented pertaining to spiritual intelligence including:

- Emmons (2000) Theory states that personal striving could become spiritual through recognizing the holy meanings in daily activities.

- Amram (2007) Theory reported a group of spiritual intelligence capabilities through some studies focused on asking participants about their spiritual practice and its influence on their work. This theory summarized the spiritual values as follows: Consciousness, Grace, Meaning of Life, and Truth.

Amram \& Dryer (2007) suggested the following five categories of spiritual intelligence:

- Consciousness: includes three minor competences: Indulgence, Attention, and Prosperity.

- Grace: includes six minor competences: Beauty, Smart, Freedom, Gratitude, Commitment, and Appreciation.

- Meaning: includes two competences: opportunity and Service

- Transcendence: includes five minor competences: Oneself Superiority, Perfection, Practice, Association, and Spirituality. 
- Truth: includes six competences: Preference, Solemnity, Internal Integration, Open-Mindedness, Responsiveness, and Confidence.

Spiritual intelligence is considered the milestone of achievement of psychological stability, where it limits its exposure to psychological disturbances such as: frustration, Anxiety, Repulsive Suspicion, and Fear.

It should be noted that psychological stability was mentioned in the Glory Quran. in Ar-Ra'd Chapter. It cites as follows: " Those who believe, and whose hearts find satisfaction in the remembrance of Allah, for without doubt in the remembrance of Allah do hearts find satisfaction, (ArRa'd, 28)".

It is clear from the above that psychological satisfaction leads to the perceiving others in a friendly manner. Also, it leads to self-acceptance, indulgence, and feeling with happiness and satisfaction.

The researcher believes that psychological stability should be available in the personality of university students. This is due to its effective role in dealing with any psychological pressure that may affect the students level of academic achievement as well as their motivation for progress.

Freud believed that the stable personality is strongly connected with his ego that protects his personality and maintains a balanced state with the surroundings. Whereas, the unstable person feels a threat to his environment, and fear from the unknown. Also, he feels with doubt toward other people, and behaves aggressively in dealing with others. Generally speaking, he cannot plan for his future.

One of the important theories that explained the psychological stability is Freud's theory of Psychological Analysis. In his theory, Fraud attributed the psychology stability to the biological and psychological law responsible for organizing human behavior. He called this law 'Principle of Pleasure', and later it is called 'Life Instinct'.

Freud believed that human personality is composed of three main powers: ID, Ego and Super Ego. As a result of analyzing these three powers, Freud concluded that the stable personality is connected with Super Ego that protects the human and keeps him in a balanced state with his environment and circumstances.

The psychological stability means that the individual enjoys a state of peace and satisfaction through his existence in a secured society, and his ability to establish stable relations with the society members. Also, the psychological stability enables the individual to receive effective learning that requires concentration, and psychological comfort free of personality disturbances. Whereas, the person who suffers psychological disturbances usually demonstrates low academic performance. 
Mahasneh et al (2015) conducted a study to explore the level of spiritual intelligence and its relationship with personality merits. The study survey sample consisted of 716 male and female students from different colleges at the Hashemite University. Two measurement tools were applied, one for personality merits and the other one for spiritual intelligence. The study results indicated an average level of spiritual intelligence of students.

Al-Obaidi (2014) conducted a study to explore the level of spiritual intelligence of students at Baghdad University. The study sample consisted of 300 male and female students. The results indicated a high level of spiritual intelligence among students. Also, the results showed the absence of any statistical indicative differences in the level of spiritual intelligence attributed to the specialty. However, it showed differences attributed to the academic level and in favor of the $4^{\text {th }}$ level students.

Al-Subheah (2013) conducted a study to explore the relationship between spiritual intelligence and achievement motivation of students at the Islamic Sciences Division. The study sample consisted of 110 male and female students. The measure of both spiritual intelligence and achievement motivation was applied. The study results showed no existing relation between the individuals' scores attributed to the variable gender, age, specialty, or academic year.

Al-Rabei (2013) conducted a study aiming at exploring the level of spiritual intelligence of students at the Educational College, Yarmouk University. The study sample consisted of 256 male and female students. The study results indicated an average level of spiritual intelligence of students. Also, it was shown no statistical indicative differences attributed to the gender.

Mira (2012) considers the psychological stability critical for accomplishing targeted objectives. The researcher could not find any research or study to investigate the relationship between spiritual intelligence and psychological stability. Therefore, he presented some studies on spiritual intelligence and other studies on psychological stability.

Khafaf \& Nasser (2012) conducted a study to explore the level of spiritual intelligence of students at Al-Mustanseriya University. The study sample was consisted of 50 male and female students. The measure of spiritual intelligence was applied. The results showed the existence of statistical indicative differences attributed to the gender in favor of females, and differences in the specialty variable in favor of humanity specialization.

A study conducted by Khaleel (2012) aimed to reveal the manner in which females treat their parents, and to explore their psychological stability. The study sample was formed of 40 female students at the Educational College for Females. Upon applying the measure of psychological stability, the results indicated a high level of psychological stability shown by the participants. 
Freeman et al (2011) conducted a study aiming at exploring the relationship between spiritual intelligence and personality manner. The study sample consisted of 480 university students. Study results reported the existence of indicative differences in the level of spiritual intelligence of students attributed gender and in favor of females.

A study conducted by Hevin (2011) aimed to explore the level of psychological stability of a sample consisted of 298 students at Dhouk University. Study results indicated a high level of psychological stability shown by the participants. Whereas, a study conducted by Al-Jumaily (2004) indicated a low level of psychological stability of some Iraqi individuals.

Arnout (2007) conducted a study aiming at exploring the relation between the spiritual intelligence and quality of life. The study sample consisted of 164 individuals from the Eastern District. The results reported the existence of statistical indicative differences in the level of spiritual intelligence of participants attributed to the gender and in favor of females. Also, the results showed Reality followed by Grace as the highest levels.

A study conducted by Al-Khazraji (2006) aimed at exploring the religious values of psychological stability, and self-recognition of a sample consisted of 812 university students. Study results indicated a high level of religious values, psychological stability, and self-recognition shown by the participants.

Based on the above, the spiritual intelligence is made up of a number of minor competences which develops with age. Also, the results of conducted studies indicated the importance of supporting and developing spiritual intelligence of university students. In addition, most study results indicated a high psychological stability level of university students.

The researcher noted that very limited studies have been conducted regarding spiritual intelligence in the Jordanian environment. For this reason, this study is being conducted to explore the relationship between spiritual intelligence and psychological stability of students at the University of Petra.

\subsection{Study Problem}

The researcher's feeling of the current study problem was emanated. This is due to the feeling that inserting spiritual issues and their development in the culture of university students is a critical need. This is due to the fact that the political, social, and cultural changes in the Arabic and Islamic areas create a real challenge for our nation. In addition, the feeling of students with psychological stability is a first priority objective that specialists try to accomplish. Therefore, 
the feeling of the study problem that addressed the relationship between spiritual intelligence and psychological stability is a major concern.

On the other hand, the connection between spiritual intelligence and psychological stability of university students may have positive effects on the educational, psychological, and social changes. Examples of expected changes are: learning motivation, self-confidence, academic achievement, social affiliation, and others. The researcher noted that it is pre-mature to confirm any relation between spiritual intelligence and psychological stability, which is considered fundamental in the educational operation.

\subsection{Study Questions}

1) What is the level of spiritual intelligence of female students in the College of Arts and Sciences at the University of Petra?

2) Are there any statistical indicative differences in the spiritual intelligence level of female students in the College of Arts and Sciences at the University of Petra, that are attributed to the variables of study level, study specialty, and GPA?

3) What is the level of psychological stability of female students in the College of Arts and Sciences at the University of Petra?

4) Is there any connection between the spiritual intelligence level and psychological stability of female students in the College of Arts and Sciences at the University of Petra?

\subsection{Study Purposes}

The study aimed to accomplish the following purposes:

- Investigate the level of spiritual intelligence of female students in the College of Arts and Sciences at the University of Petra.

- Investigate the level of psychological stability of female students.

- Investigate the differences in spiritual intelligence levels of female students, which are attributed to the variables of study level, study specialty, and GPA.

- Investigate the relationship between spiritual intelligence and psychological stability of the female students.

\subsection{Study Importance}

The importance of this study is attributed to its aim of investigating the spiritual intelligence and its relationship with the psychological stability of a sample of female students from the College of Arts and Sciences at the University of Petra. Also, the special importance of this study is mainly due to introducing a theoretical framework for the new concepts of Psychology: Spiritual Intelligence and Psychological Stability. These two concepts represent major developments of the positive psychology science that attracts the attention and interests of many international researchers. Unfortunately, the newly developed concepts do not motivate a real study in the Jordanian environment. 


\subsection{Study Concepts}

- Spiritual Intelligence: a group of mental competences based on spiritual adaptation (King, 2008). It is determined by the score achieved by the student in the measure of the spiritual intelligence used in this study.

- Psychological Stability: Feeling of satisfaction, self-acceptance, indulgence, feeling healthy and comfortable. It is determined by the score achieved by the student in the measure of the psychological stability used in this study.

\subsection{Study Limitations:}

- Subject Limitation: Spiritual Intelligence and its relationship with psychological stability.

- Human Limitation: This study is limited to female students in the College of Arts and Science at the University of Petra.

- Time Limitation: This study was conducted during the summer semester of the academic year 2017/2018.

\section{Method}

In order to accomplish the study purposes, the researcher used the descriptive analytical approach. This approach involves describing the phenomena, studying the subject, analyzing its data, and finding the relation between its variables.

\subsection{Participants}

The study society covers all female students in the College of Arts and Sciences at the University of Petra who are registered in the summer semester for the academic year 2017/2018. A total of 127 female students were randomly selected and distributed over the college specialties.

Table 1: Distribution of study sample individuals by variables.

\begin{tabular}{|c|c|c|c|}
\hline Variables & Levels & Freq. & Percentage \\
\hline \multirow{7}{*}{ Specialty } & Arabic Language & 25 & 19.7 \\
\hline & English Language & 32 & 25.2 \\
\hline & Chemistry & 16 & 12.6 \\
\hline & Educational Sciences & 22 & 17.3 \\
\hline & Modern Languages & 20 & 15.7 \\
\hline & Mathematics & 12 & 9.5 \\
\hline & Total & 127 & 100 \\
\hline \multirow{5}{*}{ Study Level } & $1^{\text {st }}$ Year & 46 & 36.2 \\
\hline & $2^{\text {nd }}$ Year & 46 & 36.2 \\
\hline & $3^{\text {rd }}$ Year & 18 & 14.2 \\
\hline & $4^{\text {th }}$ Year & 17 & 13.4 \\
\hline & Total & 127 & 100 \\
\hline
\end{tabular}




\begin{tabular}{|c|c|c|c|}
\hline \multirow{4}{*}{ GPA } & Excellent & 10 & 7.9 \\
\cline { 2 - 4 } & Very Good & 32 & 25.2 \\
\cline { 2 - 4 } & Good & 47 & 37 \\
\cline { 2 - 4 } & Fair & 25 & 19.7 \\
\cline { 2 - 4 } & Weak & 13 & 10.2 \\
\cline { 2 - 4 } & Total & $\mathbf{1 2 7}$ & $\mathbf{1 0 0}$ \\
\hline
\end{tabular}

\subsection{Study Tools}

\subsubsection{Measure of Spiritual Intelligence}

Upon reviewing several measures of spiritual intelligence, the researcher adopted the measure of Amram \& Dryer (2007). This measure was designed mainly for the university students and consisted of 60 items. This tool was modified to 47 items to match with the Jordanian environment. The tool is distributed over five areas:

- Consciousness: It means the mental condition responsible for self-awareness, and the perception capability that controls the relationship between the individual and his surroundings. This can be achieved by developing the awareness practice of mind and spirit such as contemplation, pray, and intuition.

- Grace: The ability to live in a straightforward manner, demonstrating spiritual affection to God, and being optimistic supported by faith.

- Meaning: Discover the meaning and importance of daily activities through realizing their purposes and accepting challenges and their sufferings.

- Transcendence: To avoid selfishness and be satisfied only with maximum achievement. This can be accomplished by taking care of social relationships and enjoying affection, generosity, sympathy and respect of others.

- Truth: Means the ability to live open-minded with others, and accept them with respect and affection.

In this survey, three options were given for each item: Always Applicable, Sometimes Applicable, and Not Applicable. The scores given to each response are: $3,2,1$ respectively.

Statistical scale was used to distribute the Arithmetic Averages over the measured items categorized into three levels according to the group range (1-3) as follows:

- Low Level: 1-1.66 Score

- Average Level: 1.67-2.33 Score

- High Level: 2.34-3.00 Score

The validity of the measure was investigated by seven faculty members specializing in Psychology and the curriculum of Islamic Education in Jordanian universities. The researcher took the notes of the committee into consideration. Also, the reliability of the measure was confirmed by applying it on a pilot sample, and then repeating the test on the same sample after three weeks. Then the Alpha Coefficient was calculated as shown in Table 2. 
Table 2: Reliability coefficients by using Alpha Cronbach method to test the dimensions of Spiritual Intelligence measure.

\begin{tabular}{|c|c|c|}
\hline Dimensions & N. Items & $\begin{array}{c}\text { Cronbach's } \\
\text { Alpha }\end{array}$ \\
\hline Consciousness & 11 & .862 \\
\hline Grace & 11 & .863 \\
\hline Meaning & 10 & .845 \\
\hline Transcendence & 8 & .828 \\
\hline Truth & 7 & .834 \\
\hline Spiritual Intelligence (Total) & 47 & .793 \\
\hline
\end{tabular}

It is clear from Table 2 that reliability Coefficient values of Alpha were in the range of 0.828 and 0.863 . These values are statistically indicative at level 0.01 . This indicates that Alpha measure coefficient, as whole, is 0.793, and this confirms the validity of the applied measure.

\subsubsection{Measure of Psychological Stability}

The measurement tool prepared by Al- Khazraji (2006) aims to measure the Psychological Stability of the University students. The measure consisted of 35 items covering the following five dimensions:

- Feeling Reassured

- Self-Acceptance

- Accepting Others

- Simplicity in Dealing with self and Others

- Physical and Psychological Health

The measure was reviewed by a group of Psychology Specialists at Jordanian Universities. In view of their notes and suggestions, the measure was modified to 29 items. Each item gives five options: strongly Agree, Agree, Neutral, Disagree, and Strongly Disagree. Scores of (1-5) were assigned to each responded item. Five scores were assigned to the most positive response, while one score was assigned to the most negative response.

The following statistical scale was used to distribute the Arithmetic Averages over the measured items categorized into three levels according to the group range (1-5) as follows:

- Low Level: 1-2.33 Score

- Average Level: 2.34-3.67 Score

- High Level: 3.68- 5.00 Score

In order to confirm the measure consistency, the researcher used Alpha equation for all measured dimensions. 
Table 3: Reliability Coefficient of Alpha test for all measured dimensions

\begin{tabular}{|c|c|c|}
\hline Dimensions & N. Items & $\begin{array}{c}\text { Cronbach's } \\
\text { Alpha }\end{array}$ \\
\hline Feeling Reassured & 4 & .754 \\
\hline Self Acceptance & 5 & .735 \\
\hline Accept Others & 9 & .759 \\
\hline $\begin{array}{c}\text { Simplicity in Dealing with Self and } \\
\text { Others }\end{array}$ & 5 & .734 \\
\hline Physical and Psychological Health & 6 & .855 \\
\hline Psychological Stability (Total) & 29 & .790 \\
\hline
\end{tabular}

It is clear from Table 3 that the values of Alpha Reliability Coefficient were in the range of 0.734 and 0.855 . Also, these values are statistically indicative at the indication level of 0.01. Also, it is obvious that the Alpha Reliability Coefficient of the measure, as a whole, was 0.790 , which indicates the validity of the applied measure.

\section{Results}

3.1. First Question: What is the level of the spiritual intelligence of female students in the College of Arts and Sciences at the University of Petra? The Arithmetic Averages and Standard Deviations for the scores of 127 female students on the Spiritual Intelligence measure were calculated as shown in the following Table.

Table 4: Arithmetic Averages, Standard Deviations, and ranking of the spiritual intelligence dimensions of the study sample of 127 participants.

\begin{tabular}{|c|c|c|c|c|c|}
\hline Dimensions & N. Items & Mean & S.D & Rank & Level \\
\hline Consciousness & 11 & 2.4961 & .28003 & 3 & High \\
\hline Grace & 11 & 2.4903 & .29092 & 4 & High \\
\hline Meaning & 10 & 2.4890 & .29767 & 5 & High \\
\hline Transcendence & 8 & 2.5226 & .32252 & 1 & High \\
\hline Truth & 7 & 2.5084 & .33219 & 2 & High \\
\hline $\begin{array}{c}\text { Spiritual } \\
\text { Intelligence } \\
\text { (Total) }\end{array}$ & 47 & 2.5021 & .24844 & & High \\
\hline
\end{tabular}

It is clear from the Table 4, that the Arithmetic Average of the spiritual Intelligence of the study sample participants was 2.5021, and with a standard Deviation of 0.24844 . This result indicates a high level of spiritual intelligence of female students in the College of Arts and Sciences at the University of Petra. The ranking of spiritual intelligence of the five dimensions is as follows:

- Transcendence occupied the 1 ${ }^{\text {st }}$ rank with an Arithmetic Average of 2.5226 .

- $\quad$ Truth occupied the 2nd rank with an Arithmetic Average of 2.5084

- Consciousness occupied the 3rd rank with an Arithmetic Average of 2.4961

- $\quad$ Grace occupied the $4^{\text {th }}$ rank with an Arithmetic Average of 2.4903. 
- Meaning occupied the last $\left(5^{\text {th }}\right)$ rank with an Arithmetic Average of 2.4890 .

3.2. The 2nd question: Are there any statistical indicative differences in the spiritual intelligence level of female students in the College of Arts and Sciences at the University of Petra, that are attributed to the variables of study level, study specialty, and GPA?

The answer of this question is given according to each variable.

\subsubsection{Study Level Variable}

Arithmetic Average and Standard Deviation were calculated for spiritual intelligence of female students in the college of Arts and Sciences pertaining to the study level variable (1 ${ }^{\text {st }}$ year, $2^{\text {nd }}$ year, $3^{\text {rd }}$ year, and $4^{\text {th }}$ year).

In order to determine if the differences between the Arithmetic Averages of statistical indication, the One Way ANOVA analysis was used, and the results were shown in Table 5.

Table 5: One Way ANOVA analysis for the Arithmetic Averages of Spiritual intelligence dimensions pertaining to the study level variable.

\begin{tabular}{|c|c|c|c|c|c|c|}
\hline Dimensions & & $\begin{array}{c}\text { Sum of } \\
\text { Square } \\
\text { s }\end{array}$ & $\mathrm{df}$ & $\begin{array}{l}\text { Mean } \\
\text { Square }\end{array}$ & $\mathrm{F}$ & Sig \\
\hline \multirow[t]{3}{*}{ Consciousness } & $\begin{array}{l}\text { Between } \\
\text { Groups }\end{array}$ & .330 & 3 & .110 & \multirow{3}{*}{1.415} & \multirow{3}{*}{.242} \\
\hline & $\begin{array}{l}\text { Within } \\
\text { Groups }\end{array}$ & 9.551 & 123 & .078 & & \\
\hline & Total & 9.880 & 126 & & & \\
\hline \multirow[t]{3}{*}{ Grace } & $\begin{array}{l}\text { Between } \\
\text { Groups }\end{array}$ & .453 & 3 & .151 & \multirow{3}{*}{1.820} & \multirow{3}{*}{.147} \\
\hline & $\begin{array}{l}\text { Within } \\
\text { Groups }\end{array}$ & 10.211 & 123 & .083 & & \\
\hline & Total & 10.664 & 126 & & & \\
\hline \multirow[t]{3}{*}{ Meaning } & $\begin{array}{l}\text { Between } \\
\text { Groups }\end{array}$ & .213 & 3 & .071 & \multirow{3}{*}{.799} & \multirow{3}{*}{.497} \\
\hline & $\begin{array}{l}\text { Within } \\
\text { Groups }\end{array}$ & 10.951 & 123 & .089 & & \\
\hline & Total & 11.165 & 126 & & & \\
\hline \multirow[t]{3}{*}{ Transcendence } & $\begin{array}{l}\text { Between } \\
\text { Groups }\end{array}$ & .396 & 3 & .132 & \multirow{3}{*}{1.278} & \multirow{3}{*}{.285} \\
\hline & $\begin{array}{l}\text { Within } \\
\text { Groups }\end{array}$ & 12.711 & 123 & .103 & & \\
\hline & Total & 13.107 & 126 & & & \\
\hline \multirow[t]{3}{*}{ Truth } & $\begin{array}{l}\text { Between } \\
\text { Groups }\end{array}$ & .266 & 3 & .089 & \multirow{3}{*}{.801} & \multirow{3}{*}{.496} \\
\hline & $\begin{array}{l}\text { Within } \\
\text { Groups }\end{array}$ & 13.638 & 123 & .111 & & \\
\hline & Total & 13.904 & 126 & & & \\
\hline
\end{tabular}




\begin{tabular}{|c|c|c|c|c|c|c|}
\hline $\begin{array}{c}\text { Spiritual } \\
\text { Intelligence } \\
\text { (Total) }\end{array}$ & $\begin{array}{c}\text { Between } \\
\text { Groups }\end{array}$ & .294 & 3 & .098 & & \\
\cline { 2 - 5 } & $\begin{array}{c}\text { Within } \\
\text { Groups }\end{array}$ & 7.483 & 123 & .061 & \multirow{2}{*}{1.610} & \multirow{2}{*}{.190} \\
\cline { 2 - 5 } & Total & 7.777 & 126 & & & \\
\hline
\end{tabular}

It is observed, from the Table 5, that the values of indication levels are higher than 0.05 . This indicates the equity of groups and the non-existence of indicative differences in the spiritual intelligence levels attributed to the study level variable.

\subsubsection{Specialty Variable}

Arithmetic Average and Standard Deviation were calculated for the spiritual intelligence of female students in the college of Arts and Sciences at the University of Petra pertaining to the specialty variable such as: Arabic Language, English Language, Chemistry, Educational Sciences, Modern Languages, and Mathematics. The results are given below.

Table 6: Arithmetic Averages and Standard Deviations of the dimensions of the spiritual intelligence attributed to the specialty variable.

\begin{tabular}{|c|c|c|c|c|}
\hline Dimension & Categories & $\mathrm{N}$ & Mean & S.D \\
\hline Consciousness & Arabic Language & 25 & 2.5527 & .27136 \\
\cline { 2 - 5 } & English Language & 32 & 2.3665 & .23490 \\
\cline { 2 - 5 } & Chemistry & 16 & 2.6080 & .28694 \\
\cline { 2 - 5 } & Educational Sciences & 22 & 2.5744 & .32402 \\
\cline { 2 - 5 } & Modern Languages & 20 & 2.4273 & .26397 \\
\cline { 2 - 5 } & Mathematics & 12 & 2.5455 & .22603 \\
\hline Grace & Arabic Language & 25 & 2.5236 & .27308 \\
\cline { 2 - 5 } & English Language & 32 & 2.3551 & .28966 \\
\cline { 2 - 5 } & Chemistry & 16 & 2.6307 & .23348 \\
\cline { 2 - 5 } & Educational Sciences & 22 & 2.5826 & .31324 \\
\cline { 2 - 5 } & Modern Languages & 20 & 2.4500 & .29417 \\
\cline { 2 - 5 } & Mathematics & 12 & 2.4924 & .23406 \\
\hline Meaning & Arabic Language & 25 & 2.5200 & .30687 \\
\cline { 2 - 5 } & English Language & 32 & 2.3531 & .26395 \\
\cline { 2 - 5 } & Chemistry & 16 & 2.5938 & .24075 \\
\cline { 2 - 5 } & Educational Sciences & 22 & 2.6545 & .24442 \\
\cline { 2 - 5 } & Modern Languages & 20 & 2.3550 & .31368 \\
\cline { 2 - 5 } & Mathematics & 12 & 2.5667 & .29025 \\
\hline Transcendence & Arabic Language & 25 & 2.5450 & .33048 \\
\cline { 2 - 5 } & English Language & 32 & 2.3555 & .35513 \\
\cline { 2 - 5 } & Chemistry & 16 & 2.6250 & .26615 \\
\cline { 2 - 5 } & Educational Sciences & 22 & 2.7159 & .21193 \\
\cline { 2 - 5 } & Modern Languages & 20 & 2.4500 & .30457 \\
\cline { 2 - 5 } & Mathematics & 12 & 2.5521 & .26893 \\
\hline
\end{tabular}




\begin{tabular}{|c|c|c|c|c|}
\hline \multirow{4}{*}{ Truth } & Arabic Language & 25 & 2.5543 & .35312 \\
\cline { 2 - 5 } & English Language & 32 & 2.4018 & .26525 \\
\cline { 2 - 5 } & Chemistry & 16 & 2.5804 & .34786 \\
\cline { 2 - 5 } & Educational Sciences & 22 & 2.5844 & .36062 \\
\cline { 2 - 5 } & Modern Languages & 20 & 2.4071 & .33830 \\
\cline { 2 - 5 } & Mathematics & 12 & 2.5844 & .36062 \\
\hline $\begin{array}{c}\text { Spiritual Intelligence } \\
\text { (Total) }\end{array}$ & Arabic Language & 25 & 2.5388 & .24511 \\
\cline { 2 - 5 } & English Language & 32 & 2.3671 & .20484 \\
\cline { 2 - 5 } & Chemistry & 16 & 2.6101 & .21970 \\
\cline { 2 - 5 } & Educational Sciences & 22 & 2.6215 & .25201 \\
\cline { 2 - 5 } & Modern Languages & 20 & 2.4227 & .25607 \\
\cline { 2 - 5 } & Mathematics & 12 & 2.5548 & .20318 \\
\hline
\end{tabular}

In order to determine if the differences between the Arithmetic Averages were of statistical indication, the One Way ANOVA analysis was used, and the results were shown in the Table 7.

Table 7: One Way ANOVA analysis for the Arithmetic Averages of Spiritual intelligence dimensions pertaining to the specialty variable.

\begin{tabular}{|c|c|c|c|c|c|c|}
\hline Dimensions & & $\begin{array}{ll}\text { Sum } & \text { of } \\
\text { Squares }\end{array}$ & $\mathrm{df}$ & \begin{tabular}{l|} 
Mean \\
Square
\end{tabular} & $\mathrm{F}$ & Sig \\
\hline \multirow[t]{3}{*}{ Consciousness } & Between Groups & 1.077 & 5 & .215 & \multirow{3}{*}{2.960} & \multirow{3}{*}{.015} \\
\hline & Within Groups & 8.803 & 121 & .073 & & \\
\hline & Total & 9.880 & 126 & & & \\
\hline \multirow[t]{3}{*}{ Grace } & Between Groups & 1.148 & 5 & 230 & \multirow{3}{*}{2.920} & \multirow{3}{*}{.016} \\
\hline & Within Groups & 9.516 & 121 & .079 & & \\
\hline & Total & 10.664 & 126 & & & \\
\hline \multirow[t]{3}{*}{ Meaning } & Between Groups & 1.825 & 5 & 365 & \multirow{3}{*}{4.728} & \multirow{3}{*}{.001 } \\
\hline & Within Groups & 9.340 & 121 & .077 & & \\
\hline & Total & 11.165 & 126 & & & \\
\hline \multirow[t]{3}{*}{ Transcendence } & Between Groups & 2.012 & 5 & .402 & \multirow{3}{*}{4.389} & \multirow{3}{*}{.001} \\
\hline & Within Groups & 11.095 & 121 & .092 & & \\
\hline & Total & 13.107 & 126 & & & \\
\hline \multirow[t]{3}{*}{ Truth } & Between Groups & 1.012 & 5 & .202 & \multirow{3}{*}{1.899} & \multirow{3}{*}{.099 } \\
\hline & Within Groups & 12.893 & 121 & .107 & & \\
\hline & Total & 13.904 & 126 & & & \\
\hline \multirow{3}{*}{$\begin{array}{l}\text { Spiritual } \\
\text { Intelligence } \\
\text { (Total) }\end{array}$} & Between Groups & 1.277 & 5 & .255 & \multirow{3}{*}{4.753} & \multirow{3}{*}{.001} \\
\hline & Within Groups & 6.500 & 121 & .054 & & \\
\hline & Total & 7.777 & 126 & & & \\
\hline
\end{tabular}

Table 7 indicates the existence of statistical indicative differences in the spiritual intelligence level of the study sample students that are attributed to the specialty variable in all measure dimensions, and in favor of the educational sciences. The "Truth" is the only dimension that showed no statistical indicative differences attributed to the specialty variable. 


\subsubsection{GPA Variable}

Arithmetic Average and Standard Deviation were calculated for the scores of the spiritual intelligence of female students in the college of Arts and Sciences at the University of Petra pertaining to the GPA variable. These variables were categorized as: Excellent, Very Good, Good, Fair, and Weak. The results are shown in the Table 8.

Table 8: The test of the One Way ANOVA analysis of the Arithmetic Averages of the spiritual intelligence dimensions regarding the GPA variables.

\begin{tabular}{|c|c|c|c|c|c|c|}
\hline Dimensions & & $\begin{array}{l}\text { Sum of } \\
\text { Squares }\end{array}$ & df & $\begin{array}{c}\text { Mean } \\
\text { Square }\end{array}$ & $\mathrm{F}$ & Sig \\
\hline \multirow[t]{3}{*}{ Consciousness } & Between Groups & .293 & 4 & .073 & \multirow{3}{*}{.933} & \multirow{3}{*}{.447} \\
\hline & Within Groups & 9.587 & 122 & .079 & & \\
\hline & Total & 9.880 & 126 & & & \\
\hline \multirow[t]{3}{*}{ Grace } & Between Groups & .205 & 4 & .051 & \multirow{3}{*}{.597} & \multirow{3}{*}{.665} \\
\hline & Within Groups & 10.459 & 122 & .086 & & \\
\hline & Total & 10.664 & 126 & & & \\
\hline \multirow[t]{3}{*}{ Meaning } & Between Groups & .262 & 4 & .066 & \multirow{3}{*}{.734} & \multirow{3}{*}{.570} \\
\hline & Within Groups & 10.902 & 122 & .089 & & \\
\hline & Total & 11.165 & 126 & & & \\
\hline \multirow[t]{3}{*}{ Transcendence } & Between Groups & .271 & 4 & .068 & \multirow{3}{*}{.644} & \multirow{3}{*}{.632} \\
\hline & Within Groups & 12.836 & 122 & .105 & & \\
\hline & Total & 13.107 & 126 & & & \\
\hline \multirow[t]{3}{*}{ Truth } & Between Groups & .025 & 4 & .006 & \multirow{3}{*}{.055} & \multirow{3}{*}{.994} \\
\hline & Within Groups & 13.879 & 122 & .114 & & \\
\hline & Total & 13.904 & 126 & & & \\
\hline \multirow{3}{*}{$\begin{array}{l}\text { Spiritual } \\
\text { Intelligence } \\
\text { (Total) }\end{array}$} & Between Groups & .101 & 4 & .025 & \multirow{3}{*}{.401} & \multirow{3}{*}{.808} \\
\hline & Within Groups & 7.676 & 122 & .063 & & \\
\hline & Total & 7.777 & 126 & & & \\
\hline
\end{tabular}

It is observed from Table 8 that the values of indication level are higher than 0.05. This indicates an equality of groups, and non-existence of indicative differences in the spiritual intelligence levels attributed to the GPA variable.

3.3. Third Question: What is the level of psychological stability of female students in the College of Arts and Sciences at the University of Petra? To answer this question, the Arithmetic Averages and Standard Deviations for the scores of 127 female students on the psychological stability measure were calculated as shown in the Table 9.

Table 9: Arithmetic Averages, Standard Deviations, and ranking of the psychological stability dimensions of the study sample of 127 participants.

\begin{tabular}{|c|c|c|c|c|c|}
\hline Dimension & N. Items & Mean & S.D & Rank & Level \\
\hline Feeling Reassured & 4 & 3.9803 & .68473 & 2 & High \\
\hline Self Acceptance & 5 & 4.0756 & .66520 & 1 & High \\
\hline Accept Others & 9 & 3.8119 & .46334 & 4 & High \\
\hline $\begin{array}{c}\text { Simplicity in Dealing } \\
\text { with Self and Others }\end{array}$ & 5 & 3.8598 & .69708 & 3 & High \\
\hline
\end{tabular}




\begin{tabular}{|c|c|c|c|c|c|}
\hline $\begin{array}{c}\text { Physical and } \\
\text { Psychological Health }\end{array}$ & 6 & 3.1286 & .69775 & 5 & Average \\
\hline $\begin{array}{c}\text { Psychological Stability } \\
\text { (Total) }\end{array}$ & 29 & 3.7713 & .46283 & & High \\
\hline
\end{tabular}

It is clear from Table 9 that the Arithmetic Average of psychology stability of the study sample was 3.7713 , and with standard deviation of 0.46283 . This means that the female students in the College of Arts and Sciences at the University of Petra have a high level of psychological stability. The measure of psychological stability consists of five dimensions. Self-Acceptance occupies the $1^{\text {st }}$ rank with an arithmetic average of 4.0756 . Whereas, Feeling Reassured occupied the $2^{\text {nd }}$ rank with an arithmetic average of 3.9803. The $3^{\text {rd }}$ rank was occupied by the dimension of Simplicity in Dealing with Self and Others, with an arithmetic average of 3.8598. The $4^{\text {th }}$ rank was occupied by the dimension of Accepting others, with an arithmetic average of 3.8119. Finally, the dimension of Physical and Psychological Health occupied the $5^{\text {th }}$ rank with an Arithmetic Average of 3.1286.

3.4. Fourth Question: Is there any connection between the spiritual intelligence level and psychological stability of female students in the College of Arts and Sciences? In order to answer this question, the researcher used the Person Connection Coefficient to find the relationship between the two variables, and the results were shown in the Table 10.

Table 10: Pearson Connection Coefficients between the dimensions of spiritual intelligence and the psychological stability.

\begin{tabular}{|c|c|c|}
\hline $\begin{array}{c}\text { Spiritual Intelligence } \\
\text { Dimensions }\end{array}$ & & Psychological Stability \\
\hline \multirow{4}{*}{ Consciousness } & $\mathrm{R}$ & .516 \\
\cline { 2 - 3 } & Sig* $^{*}$ & .000 \\
\cline { 2 - 3 } & $\mathrm{N}$ & 127 \\
\hline \multirow{2}{*}{ Grace } & $\mathrm{R}$ & .476 \\
\cline { 2 - 3 } & Sig $^{*}$ & .000 \\
\cline { 2 - 3 } & $\mathrm{N}$ & 127 \\
\hline \multirow{5}{*}{ Meaning } & $\mathrm{R}$ & .417 \\
\cline { 2 - 3 } & Sig $^{*}$ & .000 \\
\cline { 2 - 3 } & $\mathrm{N}$ & 127 \\
\hline \multirow{3}{*}{ Transcendence } & $\mathrm{R}$ & .434 \\
\cline { 2 - 3 } & $\mathrm{Sig}^{*}$ & .000 \\
\cline { 2 - 3 } & $\mathrm{N}$ & 127 \\
\hline \multirow{3}{*}{ Truth } & $\mathrm{R}$ & .507 \\
\cline { 2 - 3 } & $\mathrm{Sig}^{*}$ & .000 \\
\cline { 2 - 3 } & $\mathrm{N}$ & 127 \\
\hline Spiritual Intelligence (Total) & $\mathrm{R}$ & .565 \\
\cline { 2 - 3 } & $\mathrm{Sig}^{*}$ & .000 \\
\cline { 2 - 3 } & $\mathrm{N}$ & 127 \\
\hline
\end{tabular}

* Correlation is significant at the 0.01 level (2-tailed). 
The Table 10 indicates the existence of a positive statistical indicative relation between the psychological stability and spiritual intelligence with all its dimensions, and spiritual intelligence as a whole.

\section{Discussion}

The results of the current study indicated that the level of spiritual intelligence of the female students in the College of Arts and Sciences at the University of Petra was 2.5021, which is considered a high level. This result can be explained by the fact that the curriculum of students in the high school and university promote such intelligence. Also, the teachers may have an effective and positive role in this regard.

As viewed by the researcher, the spiritual intelligence is connected with the religious devotion. Also, it is noted that the religious commitment and obligations do not come from a vacuum. The religious feeling of the individual is attributed to his strong belief in the existence of God. The researcher is of the opinion that the study result is logical, as the individual grows up in a conservative society, and affected by the spiritual life around him. Therefore, the student who studies in a religious environment will live peacefully and in compliance with himself and others.

The study results were confirmed by Piaget Theory of knowledge development. It is worth noting that the university students have the ability to organize their logical thinking away from materialism. Students' awareness of spiritual life contributed to the enhancement of the spiritual intelligence level of the sample individuals.

The study results agreed with those of Arnot (2007), Freeman et al (2011), and Al-Obaidi (2014). These results showed high spiritual intelligence level of sample participants, whereas, the current study results were different from those of Al-Rabei (2013), and Mahasneh et al (2015) which reported an average level of the spiritual intelligence regarding the study sample.

In addition, the current study results showed non-existence of indicative differences between the dimensions of spiritual intelligence attributed to the study level. This means that the female students in the College of Arts and Sciences enjoy a high level of spiritual intelligence regardless of their study levels, whether it is $1^{\text {st }}$ year or $4^{\text {th }}$ year. This result can be explained by the fact that all students come from the same society, and in general come from the same social, cultural, and religious reserved class. Additionally, all students live in almost the same study environment, and interact with the same cultural activities organized by the college. In light of the above, no differences were observed between the students' levels of spiritual intelligence attributed to the study level variable. 
The study results agree with those of Al-Subheah (2013) that confirmed nonexistence of indicative differences between students' levels of spiritual intelligence attributed to the study level variable. Whereas, the study results showed differences with those results of Al-Obaidi (2014) that showed indicative differences in the spiritual intelligence attributed to the variable of study level and in favor of the $4^{\text {th }}$ year.

Also, the study results of Al-Obaidi (2014) confirmed the existence of indicative differences in the spiritual intelligence attributed to the study level variable and in favor of the $2^{\text {nd }}$ year.

The current study results indicate the existence of indicative differences in the dimension of spiritual intelligence which are attributed to the study specialty variable, and in favor of the educational sciences for most of the dimensions. This does not mean that students in other specialties of the College of Arts and Sciences have lower level of spiritual intelligence. It is mainly due to the courses with spiritual character that are offered in the educational sciences. Such courses include: principles of Faith and interpretation, Islamic Education, principles of Al-Feqh and Biography, in addition to the religious and social concepts. These courses contribute to developing students who are capable of communicating with human beings and nature in all circumstances.

The results of the current study agree with those of Khafaf and Nasser (2012) that indicated a high spiritual intelligence level of students in the Specialty of Humanity studies. Whereas, it disagrees with study results reported by AlSubheah (2013) that indicated non-existence of indicative differences in spiritual intelligence level attributed to the specialty variable.

Also, the study results showed non-existence of indicative differences in the level of spiritual intelligence attributed to the GPA. This indicates that the female students in the college of Arts and Sciences have equal level of spiritual intelligence in all dimensions including: Consciousness, Grace, Meaning, Transcendence, and Truth. The researcher believes that this result is logical. This is due to the fact that the spiritual intelligence of female students grows starting at home, then through school, and concludes at the university. This result can be connected with the previous result that showed non-existence of indicative differences in spiritual intelligence level attributed to the variable of study level. The high cumulative average is not a pre-requisite for a high level of spiritual intelligence. Also, it is not necessary for a student with a low GPA to have low level of spiritual intelligence.

The researcher noted that he is not trying to minimize the importance of the cumulative average as a variable that may contribute to lowering or raising the spiritual intelligence level of individuals. However, it happened in the current study, that the cumulative average showed no indicative effect on the spiritual intelligence level of sample students. 
As related to the psychological stability level of female students, the results revealed their enjoyment of high level of psychological stability in all its dimensions except the Physical and Psychological Health that showed an average level. This result indicated the security state of sample students and their compliance with one-self and others. With no doubt, the social environment as well as the family practice in raising up the young generation has a significant role in the psychology stability. Also, we cannot ignore the role of the university in providing students with a comfortable psychological environment that offers them self-satisfaction. Additionally, the reasonable economical situation of most students contributed to the psychological stability and created a positive attitude toward their promising future.

It is worth noting that the psychological stability enables students to control their internal excitements, accomplish their personal and social purposes, and solve their problems. With regard to the physical and psychological dimension that occupies the last rank with an average level of psychological stability, this result may be attributed to the political and economical situation of the Arab region. This situation created a negative feeling of the study sample students expressed as a psychological disturbance, fear, and frustration.

The above study results agree with the results of the studies conducted by Khaleel (2012), Hevin (2011), Al-Khazraji (2006). Their results indicated a high level of psychological stability of their study samples, with the exception of the study of Al- Jumaily (2004) that revealed a low level of psychological stability of the study sample.

Regarding the connection relationship between the two study variables (Spiritual Intelligence and Psychological stability), the study results showed a strong positive relation between the spiritual intelligence with its five dimensions and the psychological stability of female students in the College of Arts and Sciences. This means that the raising of psychological stability level is associated with the raising of the spiritual intelligence. Also, any lowering in the psychological stability level is associated with lowering of the spiritual intelligence.

The reason of the above result is due to the nature of the spiritual intelligence which represents a group of competences that enables the individual to solve his problems, accomplish his aims, and face pressures, challenges, stress and frustration.

Additionally, the spiritual intelligence helps the individual to maintain his psychological stability. Therefore, he grows up with love and hope of God, and strong commitment and obligations to his faith and religious values. The spiritual intelligence provided the human with the feelings of satisfaction, happiness, and self-confidence. 


\section{Recommendations}

In light of the study results, the researcher recommends the following:

- Providing attention and support of the Management and Faculty Members of the University of Petra to the physical and psychological health of the students through scheduling specialized courses and workshops.

- Including courses in the study plan of the Divisions of the College of Arts to develop and promote high levels of Spiritual Intelligence and Psychological Stability.

- Conducting a study to investigate the relation of Spiritual Intelligence to other variables such as: Religious Obligations, Self-Confidence, Achievement Motivation and Existence Intelligence.

\section{References}

Al-Jumaily, K. (2004). Psychological stability and its relation to some variables. Unpublished master thesis, University of Almustanseria.

Al-Khazraji,S. (2006). Religious values and their relation to psychological stability and selfknowledge among university student. Unpublished Ph.d thesis, University of Almustanseria.

Al-Masri, N. (2017). The degree of the spiritual intelligence of governmental secondary school principals in the governorate of the capital Amman and its relation to the degree of their practicing transformational leadership from teachers' point of view. Master Thesis, Middle East University, Amman.

Al-Obaidi, A. (2014). Spiritual intelligence in a sample of the university of Baghdad in the light of some variables, Journal of Educational and Psychological Research, University of Baghdad, 41, 34-53.

Al-Rabei, F. (2013). Spiritual intelligence and its relationship to gender and achievement level of students in the faculty of education at Yarmouk University in Jordan. Jordan Journal of Educational Sciences, 9(4), 364- 353.

Al-Rashed, H. (2017). The relationship between spiritual intelligence, happiness and academic achievement among secondary school students in buraidah. Master Thesis, Qaseem University.

Al-Subheah, H. (2013). Relationship between spiritual intelligence and academic achievement motivation of students of the institute of sharia science in the sultanate of Oman. Unpublished Master Thesis, University of Nizwa.

Amram, Y. (2007). What is spiritual intelligence? An ecumenical grounded theory. Working paper of the institute of transpersonal psychology, Palo, Alto, CA.

Amram,Y.,\& Dryer,C. (2007). Integrated spiritual intelligence scale: the development and preliminary validation of the integrated spiritual intelligence scale (ISIS). Working Paper Presented to Institute of Transpersonal Psychology Palo Alto, CA, 7-30.

Arnout, B. (2007). Spiritual intelligence and its relationship to personality characteristics in various arab samples. Journal of the Faculty of Education, Faculty of Education Journal, Banha University, 17(72), 125-190.

Buzan, T. (2006). The power of spiritual intelligence. 10 ways to tap into your spiritual genius. New York: taper Collins.

Dhar, N., Datta, U. \& Nandan, D. (2008). Importance of spiritual health in public health systems of india. Health and Population - Perspectives and Issues, 31(3), $204-211$.

Emmons, R. (2000). Spirituality and intelligence: problems and prospects. International Journal for the Psychology of Religion, 10 (1), 57-64. doi.org/10.1207/S15327582IJPR1001_2

Freeman,M., Hayes, B., Kuch, T.,\& Taub, G. (2011). Personality: a predictor of theoretical orientation of students enrolled in a counseling theories course. Counselor 
Education and Supervision, 46(4), 254 - 265. doi.org/10.1002/j.15566978.2007.tb00030.x

Gardner, H. (1999). Intelligence reframed multiple intelligence for the $21^{\text {st }}$ century. New York: Basic Books.

Hevin, A. (2011). Psychological stability of Duhok University students, Journal of the College of Basic Education, 10(2), 58-78.

Horn, J.L., \& Cattell, R.B. (1966). Refinement and the test of the theory of fluid and crystallized general intelligence. Journal of Educational Psychology, 57(5), 253-270. doi.org/10.1037/h0023816

Jordan, P., Ashknasy,C., \& Hartel,S. (2008). Workgroup emotional intelligence, scale development and relationship to team process effectiveness and goal focus. Human Recourses Management Review, 12(2), 195- 214.

Khafaf, E., \& Nasser, A. (2012). Students' spiritual intelligence. Journal of the College of Basic Education, 18 (75), 377-455.

Khaleel, A. (2012). The treatment of girls (charity - arrogance) of parents and their relation to psychological stability. Journal of the College of Education for Girls, 23 (1), 72-88.

King, D. (2007).The spiritual intelligence project extracting cognitive ability from the psycho spiritual , Realm/ www. bking.net /Spiritual Intelligence.

King, D. (2008). Rethinking claims of spiritual intelligence: A definition, model, and measure. Unpublished Master thesis, Trent University.

Luizcarlos, C. (2003). The ultimate meaning of viktor frank1.a demonstration project in partial fulfillment of requirements for diplomat educator / administrator credential. Vienna: Viktor Frank1 Institute of Logo Theory Press.

Mahasneh, A., Shammout N., Alkhazaleh, Z., Al-Alwan, A.,\& Abu- Eita, J. (2015). The relationship between spiritual intelligence and personality traits among Jordanian university students. Psychology Research and Behavior Management, 8, 89-97.

Mamin, M. (2008). Spiritual intelligence in executive coaching. CPCP Final Research Paper, International Coach Academy, Singapore.

Mira, A. (2012). Psychological stability and its relationship to the level of ambition at the university students. Journal of the College of Education for Girls, 23 (2), 340-359.

Saidy, E. Hassan, A. Rahman, F. Jalil, H. Ismail, I. \& Krauss, S. (2009). Influence of emotional and spiritual intelligence from the national education philosophy towards language skills among secondary school students. European Journal of Social Science, 9 (1), 61-71.

Sinetar, S. (2002). Spiritual intelligence: what we can learn from the early awakening child. Maryknoll.NY: Orbis Books.

Teichmann, M., Murdavee,M., \& Saks, K. (2006). Spiritual needs and quality of life in Estonia. social Indicators Research, 76 (1), 147-163. doi.org/10.1007/s11205-0054860-9

Vaughan, F. (2002). What is Spiritual Intelligence? Journal of Humanistic Psychology, 42(2), 16-33. doi.org/10.1177/0022167802422003

Wigglesworth. (2011). Integral theory (also called AQAL theory) and its relationship to spiritual intelligence sq assessment, www.deepchange.com.

Wilbur, K. (2001). How straight is the spiritual path? the relation of psychological and spiritual growth. in the eye of the spirit: an integral vision for the world. gone slightly mad. Boston: Shambhala Publication, Inc.

Zohar, D. \& Marshall, I. (2000). SQ: Connecting with our spiritual intelligence. New York: Bloomsbury. 